\title{
Solution for Intraocular Irrigation Dosage Form
}

National Cancer Institute

\section{Source}

National Cancer Institute. Solution for Intraocular Irrigation Dosage Form. NCI

Thesaurus. Code C149923.

Liquid sterile preparation consisting of a solution intended for irrigation of one or more internal structures of the eye, for example during surgical procedures. 